\title{
Die etos van die Hervormde Kerk in die derde millennium
}

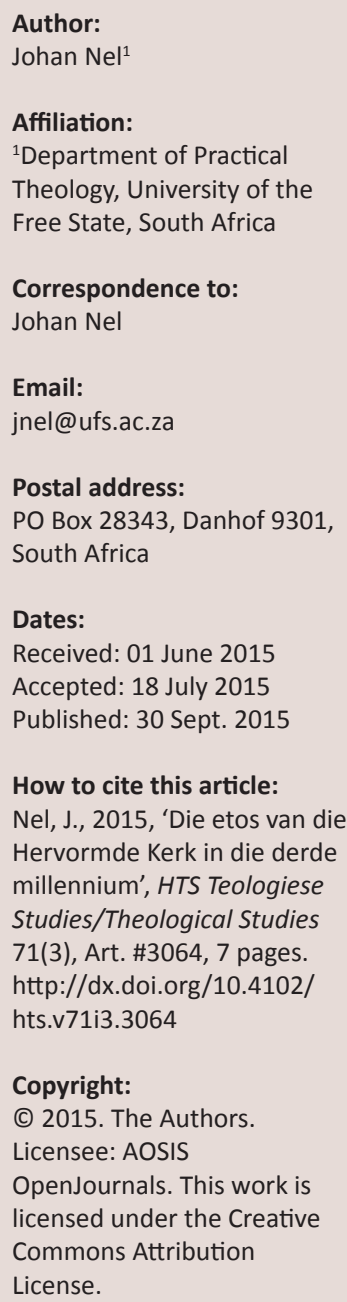

The ethos of the Reformed Church in the third millennium. This article aims at revisiting the ethos of the Netherdutch Reformed Church of Africa. There are concerns over the vast numbers of members, especially young members that leave the church. Special interest is taken in view of the ethos of the church in the third millennium. The author was curious about the understanding of members of the church as far as the ethos is concerned. A study which included two different groups within the church indicated that further investigation and research are inevitable in order to broaden the view on the future of the church even more. Factors such as the opinions of members of the church regarding the ethos and the question whether the understanding of the ethos has any impact on the declining of membership numbers could contribute to this debate.

\section{Inleiding}

In die kerklike kringe van die Nederduitsch Hervormde Kerk van Afrika (NHKA) word die woord 'etos' dikwels gebruik. Die term word telkens in verskillende kontekste op die Hervormde kerkwerf gehoor. Tydens meerdere vergaderings is dit byvoorbeeld nie vreemd dat die term deur verskillende sprekers gebruik word nie. Ook in kerklike publikasies duik die term gereeld op. Koekemoer (1994:16) oordeel byvoorbeeld dat sowel die kerklike etos as idioom voortdurend aan die Woord getoets moet word. Hy betoog dat die sogenaamde idioom van die NHKA ' $n$ teologiese vraag is. Die saak is nie so eenvoudig nie, en daarom argumenteer Koekemoer (1994:14) '... dat 'n poging om na 'n eie idioom van teologiese refleksie te soek, nie 'n maklike en vanselfsprekende aangeleentheid is nie'. Dreyer (2003:1045-1062) hanteer die etoskonsep noukeurig wanneer hy krities met statistiek van die Kerk se lidmaattal omgaan. Hierdie en ander voorbeelde word vervolgens in hierdie artikel herbesoek, soos Dreyer (1998) aan die hand doen:

Miskien moet ons weer bereid wees om onbevange die musiekskat van die Hervormde teologie te ontgin, dit byderwets te verwerk en met oorgawe te speel. Die dans sal spontaan volg, dalk met nuwe bewegings en draaie. (bl. 312)

Dreyer (1998:289-314) se artikel oor die spiritualiteit, identiteit en etos van die NHKA dui by wyse van die metafoor van musiek aan dat die kerk op pad na die derde millennium waarskynlik haar 'danspassies' sal moet aanpas. In 'n postmoderne wêreld verander die musiek voortdurend. Vir 'n Reformatoriese kerk is dit imperatief om altyd-hervormend ook die identiteit en etos van die kerk te herbesoek. Soos reeds genoem, is die term 'etos' by baie bekend, en dit wil voorkom of dit toenemend in kerklike gesprekke, debatte, artikels en akademiese aanbiedings en skryfwerk opduik.

Koekemoer hanteer reeds in 1995 op 'n versigtige wyse die konsep rondom die etos van die NHKA. Hy dui aan dat om te verwoord wat met Hervormde etos bedoel word, nie so 'n maklike saak is nie. Die saak is nie voor die hand liggend nie en sal nie in boeke teruggevind kan word nie. Koekemoer is van mening dat 'n teologie wat hoofsaaklik deur ontdekkende nederigheid gekenmerk word, moeilik oor sigself praat.

Soos genoem, word tydens kerklike vergaderings en byeenkomste dikwels na die etos van die kerk verwys waar dit voorkom asof sommige wat graag na die etos van die NHKA verwys, nie Koekemoer se siening deel dat om oor die etos te praat 'n komplekse aangeleentheid is nie. Dit wil voorkom asof daar graag en dikwels na die term verwys word met die veronderstelling dat almal op hoogte is van die bedoeling daarvan, en dan as algemeen geldende waarheid. Tydens kerklike vergaderings, byvoorbeeld, word dikwels waarderende opmerkings gemaak waarin die liturg aangeprys word omdat hy of sy die etos van die NHKA gedurende die erediens gestalte laat kry het. Spesifieke melding word dan gemaak oor die keuse van liedere en die vaste erediensorde 'soos ons dit ken en gewoond is'. Laasgenoemde uitsprake, so wil dit voorkom, 
word veral gemaak deur ampsdraers en lidmate met groot betrokkenheid by die kerk en gemeentes. Ook in kerklike publikasies, informele gesprekke en in vergaderings word die term gereeld gebruik en gehoor. Hierdie opmerkings word gewoonlik met selfvertroue gemaak.

Dit is verder opmerklik dat daar bykans sonder uitsondering op 'n positiewe wyse na die etos van die NHKA verwys word. Die vraag ontstaan egter of elkeen se definisie van die term met die res ooreenstem.

Dit wil inderdaad voorkom asof daar ten spyte van die positiwiteit rondom die sogenaamde etos onderliggende verskille bestaan oor die inhoud, begrip en uiteindelike sentiment rakende die term. Hierdie artikel sal vervolgens ook uitwys dat daar, minstens wat die respondente in die artikel betref, sekere lidmate en kerkraadslede is wat nog nie van die term gehoor het nie of onseker is daaroor. Hoewel dit nie noodwendig so hoef te wees dat elkeen met die tegniese term vertroud behoort te wees nie, behoort daar wel instemming te wees oor die bedoeling daarvan. Dit is nie altyd die geval nie en sal mettertyd uitgewys word.

\section{Vraagstelling}

Verskillende vrae ontstaan wanneer oor die etos van die NHKA gepraat word. Dit is belangrik dat elkeen wat die term gebruik, dieselfde bedoeling met die gebruik daarvan sal hê. Waar dit nie die geval is nie, bestaan die gevaar dat almal dit klakkeloos aanvaar en by implikasie met die bedoeling van die spreker instem. Die vraag ontstaan verder of daar inderdaad algemene konsensus bestaan oor wat onder die term etos of die implikasie van die term verstaan word. Die outeur se waarneming is dat wanneer daar van die NHKA se etos gepraat word, daar van die veronderstelling uitgegaan word dat die hoorders daarvan volledig instem met die inhoud daarvan. Die navorsing toon egter 'n dissonansie tussen bedoeling en begrip.

Die NHKA is pas deur ' $n$ bitter tyd van skeuring, agterdog en onderlinge verskil. Die effek van die kerkskeuring sal waarskynlik in die komende geslagte steeds gevoel kan word. Sowel die groepering wat weggeskeur het as die lidmate wat steeds lidmate van die NHKA is, maak daarop aanspraak dat hulle die etos van die NHKA adem.

Soos genoem, het hierdie artikel dit nie oor die inklusiwiteit van die term nie. Dit wil eerder probeer om vas te stel of die lidmate van die NHKA werklik bewus is van wat die etos van die kerk inderwaarheid behels en watter betekenis hulle daaraan heg. 'n Verdere vraag ontstaan noodwendig: Wat sê die Hervormde lidmaat in die derde millennium oor die etos van die NHKA? Die term is om die minste te sê, uiters gelade. Predikante, ampsdraers en lidmate behoort daarom te verstaan wat met die term bedoel word. Die rede hiervoor is dat wanneer oor die Kerk, haar gebruike en voortbestaan gehipotetiseer word, elke toehoorder 'n duidelike begrip behoort te hê oor die betekenis van die terme wat gebesig word. Sinvolle deelname en debattering is andersins nie moontlik nie. Dit is derhalwe imperatief dat uitklaring gekry moet word rakende die term.

Om van verskille in interpretasie bewus te wees, sou daartoe kon bydra dat die term nie nogeens die kiem van 'n etiket huisves wat nuwe polarisering binne die NHKA in die hand kan werk nie. Die kerk se geskiedenis vertoon ' $n$ veelheid van skakerings waarby onvergenoegdheid en konflik dikwels die botoon voer.

\section{Metodologie}

Die artikel maak gebruik van kwantitatiewe navorsing. Twee groepe lidmate se menings is met behulp van oopeindevraelyste getoets. Daar is ook 'n aanvullende literatuurstudie onderneem om vas te stel hoe daar reeds met die term ter sprake omgegaan is. Sodoende word die nuwe navorsing met die bestaande in gesprek gebring. Verder is daar hoofsaaklik op deelnemende-aksie-navorsing gefokus. Daarom is navorser en deelnemers gelyke vennote in die proses, 'n subjek-subjek skema (De Vos 2002:419). Die eerste stel vraelyste is tydens twee ringsvergaderings aan afgevaardigdes beskikbaar gestel. 'n Totaal van 35 vraelyste is uitgedeel en terugontvang. Die voordeel van hierdie werkswyse was dat die navorsing ter plaatse gedoen is en dat almal wat die vraelyste voltooi het se betrokkenheid by die NHKA sodanig is dat hulle per geloofsbrief deur hulle kerkrade na 'n ringsvergadering afgevaardig is. Daar is egter ook sekere beperkings, byvoorbeeld dat die afgevaardigdes na 'n ringsvergadering nie noodwendig verteenwoordigend is van die deursnee-lidmaat van die NHKA nie. Verdere beperkings kom daarin na vore dat die reaksie slegs 'n beperkte hoeveelheid lidmate se persepsie verklank. Ten spyte van hierdie beperkings kan daar wel voorlopige waarnemings gemaak word wat deur middel van 'n uitgebreide studie getoets en verdiskonteer kan word. In die opvolgstudie sal kwalitatiewe navorsing gebruik word. In-diepte onderhoude wat hieruit sal voortvloei, behoort 'n veelheid nuwe insigte na vore bring. Op hierdie wyse kan die ervarings en persepsies van lidmate deeglik verreken word.

Die tweede stel vraelyste is uitgedeel aan 'n groep wat hoofsaaklik bestaan uit studente en jong werkendes wat belydenis van geloof in die NHKA afgelê het en steeds lidmate van die Kerk is. ' $n$ Totaal van 20 respondente is by hierdie deel van die navorsing betrek. Die resultate van Dreyer (2003) se empiriese bevindings het grootliks bygedra tot die verstaan van die konteks en die implisiete narratief van die statistiek en het so 'n groot bydrae gelewer. Dit is egter opmerklik dat daar tot op hede baie min sodanige studies onderneem is. Die gevaar bestaan derhalwe dat veralgemenings kan voorkom. Die noodsaak aan 'n uitgebreide opvolgstudie word hierdeur bevestig. So 'n studie word deur die outeur in die vooruitsig gestel. In die opvolgende studie sal kwalitatiewe navorsing ook ingesluit word. Die resultate van die huidige navorsing is derhalwe slegs voorlopig. 
Osmer (2008) is van mening dat die metode van die navorsing deur die strategie van die navorser bepaal word. Hierdie navorsing het ten doel om as eerste stap verkennend te werk te gaan ten einde eerstens die vermoede van die outeur te bevestig. Uiteraard is daar baie beperkings aan hierdie navorsing verbonde. Onderhoudvoering mag inligting belig wat nie noodwendig deur die gebruik van vraelyste verkry sou word nie. Hulle glo egter dat die onderhoudvoering net so onbetroubaar kan wees soos die reaksie uit die vraelyste. Hieruit word dit duidelik dat verskillende navorsingsmetodes hulle eie voor- sowel as nadele het. Die keuse is uiteindelik gemaak vir oopeindevraelyste.

Die doel van die ondersoek is om by die lidmate self te verneem hoe hulle die NHKA beleef en hulle persepsie rondom die etos van die NHKA te toets.

Soos genoem, word 'n meer omvangryke studie in 'n volgende artikel in die vooruitsig gestel nadat die problematiek rondom ' $n$ definisie verdiskonteer is.

\section{Kontoere van 'n etos}

Dreyer (2003:1046) wys daarop dat die kerk binne die teologiese tradisie van die NHKA gewoonlik in terme van dogmatiese, kerkregtelike en belydenismatige uitsprake gedefinieer word. Die basiese vertrekpunt is die suiwer Woordverkondiging en sakramentsbediening, asook die handhawing van die kerklike dissipline. Hy waarsku teen die valse gerustheid wat hierdie uiterlike kenmerke van die kerk dikwels skep en dat dit soms teen die aandrang om vernuwing gebruik word. Hierdie uitspraak van Dreyer is reeds meer as 'n dekade gelede gemaak. Ons leef tans inderdaad alreeds in die derde millennium.

Mead (1994:17) wys daarop dat daar in die Christendomparadigma van bo na onder gedink en gedoen word. Die evangelie is van bo deur die teoloë en deur die instituut na die gewone lidmaat oorgedra. Daar was genoeg outoriteit en dissipline om die gesag 'van bo' te handhaaf. Sekularisasie en die postmodernisme het die konteks totaal verander.

There are many who argue that people want security and clear answers, and that it is the responsibility of the church to provide them with such clear and definite answers. (Meylahn 2012:17)

Volgens hom is dit waar dat mense 'n behoefte aan sekuriteit ervaar, maar hy waarsku dat dit gevaarlik is om aan mense valse sekuriteit te gee. Enige sisteem of verhaal of interpretasie (en durf ons sê, etos) wat daarop aanspraak maak om die aller-antwoord te bied, is 'n geslote sisteem. Meylahn (2012:17) poneer voorts dat enige geslote sisteem altyd die ander sowel as die tyd sal uitsluit '... and therefore, even those who might at first feel secure, will eventually feel confined and restricted because they have to interpret and understand their multiple experiences everyday...' Die lewe is kompleks en dinge wat onverstaanbaar is, gebeur. Dit is dus waar dat mense vastigheid en sekuriteit nodig het, maar hierdie sekuriteit mag nie vals wees nie. Die kerk behoort uiteindelik 'n liefdevolle inklusiewe gemeenskap te wees.

\section{Hoe is die etos van die NHKA in die verlede verstaan en gedefinieer?}

Die volgende kan as wesenskenmerke van die etos van die NHKA uitgelig word.

Die Hervormde teologie bepaal die etos van die NHKA en word tegelyk weer deur die etos bepaal (Koekemoer 1995:877). Koekemoer meld verder dat Hervormde teologie nog altyd vasgehou het aan die begrip van die waarheid as ontmoeting. 'Teologie is nie 'n esoteriese bedryf nie. Dit is denkarbeid ten dienste van die kerklike verkondiging waarin die belydenistradisie ernstig geneem word' (Koekemoer 1995:878).

Dreyer (1998:289-314) omlyn die onderlinge verband en interafhanklikheid tussen spiritualiteit, identiteit en die bepaalde kerklike etos.

Buitendag (2003:353-365) is van mening dat kerklike etos 'n persepsie is wat by wyse van akkoord deur sommige aanvaar kan word as iets van hulle eie belewenisse wat op ' $n$ manier verwoord is. 'Dit is maar enkele pennestrepe oor die subjektiewe simbiose van 'n enkeling binne die eksistensiële bedding van sy geestelike tuiste' (Buitendag 1992:1). Buitendag wys verder in sy memorandum daarop dat die groeibodem van die NHKA slegs vanuit die etiese teologie gedurende die negentiende eeu in Nederland verstaan kan word. Daar word etos verstaan as die nadere kwalifisering van teologiese waarhede, of die etiese karakter van die waarheid. Dreyer (1998:303) meen '[d]it sou op oorvereenvoudiging neerkom as bloot aanvaar word dat die etiese teologie deurslaggewend is vir die teologiese denke van die Hervormde Kerk'. Hy wys daarop dat ook ander invloede aan die vorming van 'n Hervormde teologie meegewerk het. Dreyer se definisie van die etos van die Hervormde Kerk vind dan neerslag in die Hervormde Teologie, wat die spiritualiteit bepaal. Hy meld verder dat die etos van 'n kerk in bepaalde gebruike en gewoontes in die erediens, prediking en die lewe van die gemeente neerslag vind:

Die spiritualiteit van die Hervormde Kerk vind in die Prediking, liturgie, gebed, sang en gemeentelike lewe daarin gestalte dat dit deur soberheid, gewydheid en nederigheid gekenmerk word... Kerkmusiek en sang wat byderwets gepopulariseer word, skaad hierdie Godservaring. Optogte, T-hempies en aksies om jou liefde vir Jesus te demonstreer, vervlak die lewe voor God tot alledaagse sosiale aksies. (Dreyer 198:305)

Van Eck (2011) toon aan dat Dreyer, wat die etos van die NHKA betref, 'n rigtinggewende bydrae gelewer het. Die stelling word gemaak dat die etos van 'n kerk niks met die betrokke kerk se gebruike en tradisies te make het nie. Die eintlike saak waaroor dit gaan, is die diepliggende, die teologiebeoefening. Uit die reaksie van die navorsing sal weldra blyk dat dit juis op hierdie punt is dat die leemte bestaan: Die inhoud van die etos en die verstaan daarvan deur lidmate stem nie ooreen nie. 
Van Eck (2011) verwoord Dreyer se bedoeling verder deur te meld dat die Bybels-Reformatoriese teologie van die kerk in 'n bepaalde spiritualiteit en identiteit tot uitdrukking kom. Dit is noodsaaklik dat die kerk solidêr krities met haar etos moet omgaan.

In die derde millennium moet indringend gekyk word of die spiritualiteit van byna twee dekades gelede steeds in die harte van lidmate van die Kerk leef. Die kerk moet vir sigself uitmaak of dit nog steeds (in Dreyer se woorde) wat spiritualiteit betref sober, nederig en gewyd is en wil wees (Dreyer 1998:305). Dit wil voorkom asof 'n paradigmaskuif intussen plaasgevind het en dat daar wel ' $n$ behoefte by sommige lidmate ontstaan het om hulle liefde vir Jesus by wyse van aksies, en selfs T-hemde, te demonstreer! Dit is algemeen bekend dat die aandrang op byvoorbeeld gepopulariseerde kerkmusiek aan die toeneem is. Trouens, dit is in verskeie gemeentes reeds praktyk. Hierdie saak beland ook toenemend op die tafel van die Algemene Kerkvergadering.

Ook in die GKSA is die vraag lankal reeds gevra of dié kerk die gereformeerde spiritualiteit in ' $n$ postmoderne gemeenskap kan behou (Smit \& Vorster 2000:516). Hierdie vraag in die GKSA toon veel raakpunte met die NHKA.

'n Volgende vraag is of die etos van die NHKA nie eerder as dubbelkantig beskou behoort te word nie. Hiermee word bedoel 'n onderskeid tussen teorie en praktyk, tussen teologie en spiritualiteit. Oor die teologie moet almal saamstem, maar verskillende spiritualiteitstipes mag nie geïgnoreer word nie. Anders gestel: Veronderstel dat die teologiese uitgangspunte van die NHKA slegs een, spesifieke spiritualiteit impliseer en dat slegs daardie spiritualiteitstipe vir die kerk in alle kontekste aanvaarbaar is?

Dit kom voor asof daar in die verlede redelike konsensus bestaan het dat die Hervormde spiritualiteit een van soberheid en nugterheid is. Die vraag ontstaan egter of die aanname steeds gemaak kan word? Uit die gesprekke met die tweede (jonger) groep respondente sal dit mettertyd duidelik blyk dat hierdie aanname baie voetangels het. Hoe lyk die toekoms dan wanneer die opkomende geslag min of geen erg aan die sentimente van die vorige geslag(te) het nie?

\section{Die rol van die postmodernisme}

Vorster (1999:106) onderskei drie tydperke of makroparadigmas: dié van die premodernisme, dié van die modernisme en dié van die postmodernisme. Die premodernisme duur tot die dertiende eeu. Dit is die tyd waarin die klem val op metafisiese kragte in die wêreld in 'n lewe wat om voortbestaan per se wentel. Die geloofsfunksie oorheers die rede gedurende hierdie tydperk (Heelas 1993:109). Vervolgens is daar die modernisme waarin die oorheersing van metafisiese kragte deur die oorheersing van die rede vervang word (Smit \& Vorster 2000:517). Godsdiens word nou bevraagteken, en die mens sien sigself toenemend as die bepaler van 'n eie bestemming (McGrath 1992:132). Die derde makro-paradigma, die postmodernisme, het in die twintigste eeu sy volle beslag gekry. Dit is veral na die Tweede Wêreldoorlog dat dié paradigma stukrag kry.

Janse van Rensburg (2000:5) meen dat alle postmoderniste daaroor saamstem dat daar geen vaste kennis of interpretasie moontlik is nie. Daar is geen absolute waardes nie weens die beginsel van verskil: '... no structure to the text and therefore no fixed interpretation' (Janse van Rensburg 2000:5). Müller (1996:55) beskryf die postmodernisme as dat geen absolute waarhede en sekerheid bestaan nie. Die postmodernisme bestaan uit ' $n$ wantroue in die objektiewe waarhede (Janse van Rensburg 2000:5). Die supersosiale strukture wat deur die mens self tot stand gebring is, word nou deur die mens self bevraagteken (Smit \& Vorster 2000:518). Relativisme word 'n gonswoord binne hierdie paradigma.

Dit is algemeen bekend dat die Kerk - universeel gesproke met die realiteit van die postmodernisme gekonfronteer word. Die Kerk en haar lidmate leef binne die paradigma van postmoderniteit en moet derhalwe van die impak hiervan op die praktyk van kerkwees kennis neem. Individue, wat te midde van hierdie tydsgees leef, sal noodwendig vingerafdrukke daarvan dra. Die Bybels-Reformatoriese teologie staan vas. Waar dit egter in praktiese kerkwees uitmond, ontstaan daar dikwels 'n dissonansie. Sonder om die baba saam met die badwater uit te gooi, behoort die invloed van die postmodernisme deeglik verdiskonteer te word soos Smit en Vorster (2000) die stel:

Hierby kan gevoeg word dat die vraag nie meer is, soos in die modernisme, of geloof 'n geldige antwoord op die mens se lewensvraagstukke bied nie. Die vraag is nou of één bepaalde geloof noodwendig 'n geldige antwoord op die mens se lewensvraagstukke kan bied. (bl. 518)

Geloof en spiritualiteit is nie sinoniem nie. Die uitlewing van geloof in 'n postmoderne wêreld sal waarskynlik 'n toenemende verdraagsaamheid teenoor verskillende spiritualiteitstipes aan die orde bring.

Louw (1999:19) se antwoord op die spanning lê daarin dat mense normatiwiteit, wat nou geskakel is met Christelike perspektiewe, nodig het. Hy oordeel dat 'n normatiewe benadering as ' $n$ sinsraamwerk beskou kan word waar mense opnuut na sekuriteit soek. Binne hierdie sinsraamwerk kan moderne mense keuses uitoefen wat die kwalitatiewe waarde van hulle bestaan, tesame met die voortgang van 'n menswaardige bestaan, in ag neem.

Kuhn (1987:82) is van mening dat 'n nuwe paradigma nie deur 'n individu of 'n groep geskep word nie, maar dat dit eerder binne' $n$ konteks van verskeie sosiale en wetenskaplike faktore tot rypheid groei. Dat daar 'n onmiskenbare paradigmaverskuiwing plaasgevind het, is 'n algemeen erkende feit, trouens dit is reeds twee dekades gelede erken (Bosch 1992:181). 
Smit en Vorster (2000) wys daarop dat die postmodernisme ook benaderingswyses na vore bring wat positief waardeer moet word:

Die verset teen die mag van die rede, wetenskap en tegnologie bring weer die eg menslike kwaliteite van ervaring, gevoel, die betekenis van die individu en ' $n$ wegbeweeg van ' $n$ witswart-, simplistiese reg-verkeerd-skemas na die sentrum van waardeoordele na vore. (bl. 519)

Verder bring die nuwe belangstelling in die metafisiese 'n nuwe erkenning van die bestaan van God en die mens se inherende godsdienssin na vore.

Die verandering in paradigma het ingrypende implikasies vir die NHKA. Die NHKA in die derde millennium kan nie dieselfde bly nie. Dit sou stagnasie impliseer, wat binne 'n Bybels-Reformatoriese oortuiging onhoudbaar is. 'n Volgende, belangrike vraag is: Sal die NHKA wat spiritualiteit betref in die derde millennium dieselfde kan bly? Browning (1991) meen dat verandering onafwendbaar is:

... you cannot separate theory from praxis, because our praxis (the way we interpret our experience and the way we give words to our experience) is determined by the tradition, the knowledge, the language and thus the theory ... (bl. 1)

Ek moet weereens herhaal: 'n Reformatoriese kerk durf nie stagneer nie. Ook wat spiritualiteit betref, is lidmate blootgestel aan die veranderende tendense wat wêreldwyd plaasvind, en hulle durf nie geïsoleerd probeer leef nie.

Dit is verder belangrik om rekening te hou met tyd en omstandighede, soos Meylahn (2012) reeds aangetoon het. Gadamer (1989:276) maak melding van die bevooroordeeldheid van die kyker wat die wêreld waarneem en beskou, en stel dat juis hierdie vooroordele sal bepaal hoe die wêreld waargeneem word.

\section{Respondente aan die woord}

Ten einde ' $n$ beeld te verkry van hoe lidmate van die NHKA die term etos beskou en verstaan, was dit nodig om uit hulle eie monde te hoor hoe hulle hieroor dink. Aangesien die eerste groep respondente almal afgevaardigdes na ringsvergaderings was, kan die stelling gewaag word dat hierdie lidmate binne die hart van die kerk funksioneer.

Twee groepe respondente is by die navorsing betrek: Die eerste kategorie bestaan uit 35 respondente wat verspreid is oor die spektrum van ouderdom, geslag en aantal diensjare. Hierdie lidmate verteenwoordig stedelike, voorstedelike asook plattelandse gemeentes. Daar is kortliks aan die respondente verduidelik dat 'n ondersoek geloods word ten einde te bepaal hoe die etos van die kerk deur die kerk verstaan word en hoe dit neerslag vind in die gemeentes waar hulle dien. 'n Kort definisie van die term ter sprake is aan die respondente verduidelik. Ten slotte is die vraag gevra wat hulle persoonlike verstaan van die etos van die NHKA is. Vertroulikheid is gewaarborg, en die nodige toestemming is verkry om die gegewens in 'n navorsingsverslag te gebruik.

Die tweede kategorie respondente het bestaan uit 20 jong lidmate waarvan 14 studente en 6 jong werkendes was (insluitend een getroude egpaar). Weer is die versekering van anonimiteit gegee, met die nodige toestemming om die gegewens in 'n navorsingsverslag te vervat.

Die doel van die ondersoek was om by die lidmate self te verneem hoe hulle die NHKA beleef. Hierdie belewenis sluit die meeste fasette van kerkwees in: teologie, liturgie, spiritualiteit en uiteindelik ook die etos van die kerk. Dit is belangrik om daarop te let, en dit sal ook so aangetoon word, dat die tweede groep lidmate, naamlik die studente en jong werkendes, hoofsaaklik vanuit 'n postmoderne posisie reageer. Hulle is inderdaad kinders van hulle tyd.

Wanneer die reaksie van beide groepe onder die loep geneem word, kan daar ' $n$ beeld gevorm word van wat in die harte van lidmate leef, wat weer kan bydra tot nuwe praktykteorieë binne die bestaande praksis. Die veronderstelling is nie dat hierdie klein steekproef ' $n$ hele nuwe beweging moet aktiveer nie, maar dat daar ten minste met verantwoordelikheid gekyk en geluister sal word.

Die vrae konsentreer op die volgende aspekte:

- waardering vir die kerk

- leemtes wat beleef word

- opinie rondom die etos van die kerk of wat die manier van kerkwees beteken

- belewenis van ander kerke (waar van toepassing).

Die vrae het in die twee groepe navorsingsgenote die volgende antwoorde opgelewer:

\section{Groep 1: Predikante, ouderlinge en diakens}

Weergegee nadat die vraelyste geanaliseer en geïnterpreteer is, in volgorde van belangrikheid

Ons kerk se sterk punte is ...

- suiwer woordverkondiging

- erns met die teologie

- persoonlike kontak

- ons liturgie

- sakramente

- tradisies

- geloofsbelydenis

- orde in die kerk

- vernuwend, maar behoudend

- barmhartigheid

- die behoud van vormgodsdiens met betrekking tot die lees van die wet en geloofsbelydenis

- kleiner, meer intieme gemeentes

- ons ken mekaar

- 'n mate van behoudendheid, maar bereidheid om te vernuwe. 
Het jy al van die term 'etos' van die Hervormde Kerk gehoor?

$\begin{array}{ll}\text { - Ja } & 35 \% \\ \text { - Nee } & 55 \% \\ \text { - Onseker } & 10 \%\end{array}$

Wat my bekommer van ons kerk, is ...

- verlies aan lidmate

- toenemende verlies aan jongmense

- gemeentes raak bedieningsgewys uit voeling met die wêreld om hulle

- kerk is besig om 'toe te gee', wil soos ander kerke word ter wille van getalle

- wet en belydenis word nie meer elke Sondag gelees nie

- belangeloosheid by lidmate

- al die roerings in die kerk.

My verstaan van die term 'etos van die Hervormde Kerk', is ...

- die kerk se eiesoortige werkswyse

- die identiteit van die kerk

- dit wat van jou 'n ware Hervormer maak

- gerig na God en na buite

- liefde, eerbaarheid, geloof

- gebruike en manier van doen

- dit is die missie van die kerk

- die diensboek

- ek weet nie $(60 \%)$.

Ons kan by ander kerke leer ...

- bedieningstyle

- musiek wat eietyds is

- hoe om sending te doen

- hoe om 'n warm atmosfeer te skep

- hoe om jongmense en kinders te bereik en as lidmate te behou

- ander kerke kan meer by ons kom leer as wat ons by hulle kan leer.

Vanuit die reaksie kan die volgende afgelei word:

- Hierdie groep lidmate voel positief oor die kerk.

- Hulle is aktief by die kerk betrokke en neem deel.

- Hulle is gelukkig in en met die kerk.

- Daar is wel enkele sake waaroor hulle besorg is.

- Verlies aan lidmate kwel hulle veral.

- Daar is 'n openheid by die meeste om akkommoderend te wees

- Hulle vra nie te veel vrae nie.

- Hoewel hulle meestal nie bekend is met die term 'etos' nie, is dit uit hulle antwoorde duidelik dat hulle die gees van die term begryp. Kerk en etos beteken vir hierdie groep dieselfde, wat die bruikbaarheid van die reaksie problematiseer. Die feit dat 'n leemte in begrip hier uitgewys word, bied 'n geleentheid tot oordra van inligting, wat andersins nie aangetoon sou kon word nie.

\section{Groep 2: Studente en jong werkendes}

Uit hierdie groep het die oorgrote meerderheid studente gemeld dat hulle selde ' $n$ erediens in die Hervormde Kerk bywoon. Die meerderheid studente woon hoofsaaklik tydens vakansietye eredienste saam met hulle ouers by wanneer hulle in hulle tuisgemeentes is. Hulle woon gereeld die byeenkomste van ander kerke en denominasies by. Die betrokke kerke wat deur hierdie groep besoek word, is bekend vir die fokus op die behoeftes van lidmate om diensbaar te wees. Selgroepbediening en uitreik-aksies in die plaaslike gemeenskap en veral ook missionêr oor landsgrense heen staan uit as redes waarom jongmense by spesifieke groepe betrokke raak. Verdere redes wat opgemerk is, word aangedui as dat die eredienste gemaklik en informeel is en die prediking aktueel en relevant, op die man af.

Ons kerk se sterk punte is ...

- Van die preke is goed en suiwer.

- Sommige mense is ernstig oor hulle geloof.

Het jy al gehoor van die term 'etos' van die Hervormde Kerk:

- Ja $0 \%$

- Nee $\quad 90 \%$

- Onseker $10 \%$

Opmerking: Die feit dat geen persoon uit hierdie kategorie bekend is met die term nie, is insiggewend. In die inleiding tot hierdie artikel is reeds melding gemaak van die leemte: Taal word gebesig terwyl die hoorders daarvan nie die bedoeling daarvan ken nie.

Wat my bekommer van ons kerk, is ...

- Die kerk plaas Christus nie sentraal nie.

- Daar is nie geleenthede om diensbaar te wees nie.

- Die musiek hou nie tred nie.

- Mense is skynheilig en skinder baie.

- Daar is baie konflik.

- Lidmate se leer en lewe stem nie ooreen nie.

- Alles gaan om geld en fondsinsamelings.

- Die lidmate is baie veroordelend en onverdraagsaam teenoor ander wat nie soos hulle dink nie.

- Hervormers dink dis net hulle wat gered is.

- Niemand gee vir jonger lidmate om nie.

- Ek mag nie 'n mening oor iets uitspreek nie.

My verstaan van die term 'etos van die Hervormde Kerk', is ...

- $\quad$ weet nie $(80 \%)$

- die manier waarop kerk gehou word of die tradisie of die manier van doen $(10 \%)$.

Ons kan by ander kerke leer...

- dat dit oor Christus as die middelpunt gaan

- van Geesvervuldheid

- dat kerkwees nie na binne gerig behoort te wees nie

- hoe om 'n verskil te maak 
- om nie veroordelend te wees oor almal nie

- van opregtheid

- dat lidmate wil dien

- hoe mense hulle gawes kan uitleef.

Vanuit die reaksie van hierdie groep kan die volgende afgelei word:

- Die lidmate is ernstig oor hulle geloof.

- Hulle is kinders van hulle tyd (postmoderniteit).

- Hulle wil verstaan voordat hulle aanvaar.

- Hulle het 'n behoefte aan diensbaarheid.

- Respek word verdien, nie toegesê nie.

- Hulle is gefrustreerd omdat hulle veroordeel voel wanneer hulle nie met die kerk saamstem nie.

- Hulle het nie veel aan die etos van die kerk nie.

- Hulle het 'n behoefte aan aanvaarding, warmte en opregte omgee.

- Hulle beleef verskillende spiritualiteite.

\section{Gevolgtrekking}

Hoewel daar, soos aanvanklik uitgewys, gereeld van die term 'etos' gebruik gemaak word, blyk dit uit die navorsing dat die gereelde gebruik van die woord nie die indruk moet skep dat die term deur almal begryp word en dat die kerkvolk instemming daaroor toon nie. Die leemte is in die volgende geleë: die aanname van die gebruikers van die term dat die hoorders noodwendig presies weet waarna hulle verwys. Die uitdaging lê waarskynlik onder andere daarin dat 'n begripsverheldering moet plaasvind.

Dat daar inderdaad reeds groot paradigmaskuiwe in die eerste jare van die derde millennium plaasgevind het, is duidelik. Die skuiwe het hoofsaaklik plaasgevind onder die opkomende geslag, diegene in hulle vroeë volwassenheid. Dit wil voorkom asof die kerk nie voorbereid is hierop nie, hoewel daar dikwels stemme opgaan om daadwerklik 'iets' aan die toenemende verlies aan lidmate te doen. Die relevansie van die sogenaamde etos van die kerk lê daarin dat die verlies aan lidmate moontlik verband kan hou met die ongeërgdheid van lidmate oor 'n spiritualiteit (met inbegrip van 'n etos), wat vir baie reeds uitgedien en irrelevant geraak het. Hierdie hipotese moet in verdere navorsing aan die orde kom.

Die uitdaging is kompleks. Hoe akkommodeer ons sonder om prys te gee? Hoe behou ons sonder om self te vervreem? Hoe behou ons ons jongmense sonder om ons ouer lidmate te verloor? Meer nog, hoe vorm ons 'n praksis waarin die Bybels-Reformatoriese teologie steeds ononderhandelbaar is, terwyl nuwe weë tog gebaan moet word?

Om hierdie vrae te antwoord, is nie maklik nie. Meer en indringende navorsing is noodsaaklik. Navorsing sal noodwendig deelnemend moet plaasvind, die vennote sal mekaar op gelyke vlak moet ontmoet. Bevooroordeeldheid en 'n gearriveerde of meerderwaardige houding dra reeds die kiem van die dood in die pot.

Dreyer (2003:1060) se bevinding van byna twee dekades gelede sal herbesoek moet word, om vas te stel of dit steeds geld: '... [dit] het geblyk dat hulle [lidmate] nie graag die teologiese etos van die Hervormde Kerk wil verander nie. Dit bied aan hulle 'n geestelike tuiste en geborgenheid.'

\section{Erkenning Mededingende belange}

Die outeur verklaar dat hy geen finansiële of persoonlike verhouding(s) het wat hom op 'n voordelige of nadelige wyse in die skryf van die artikel beïnvloed het nie.

\section{Literatuurverwysings}

Bosch, D.J., 1992, Transforming mission: Paradigm shifts in theology of mission, Orbis Books, New York, NY.

Browning, D., 1991, A fundamental practical theology: Descriptive and strategic proposals, Fortress Press, Minneapolis, MN.

Buitendag, J., 1992, 'Die etos van die Nederduitsch Hervormde Kerk', ongepubliseerde memorandum in Handelinge van die TKK, Argief van die Nederduitsch Hervormde Kerk, Pretoria.

Buitendag, J., 2003, 'Die kerk se korporatiewe identiteit', HTS Teologiese Studies/ Theological Studies 59, 353-365. http://dx.doi.org/10.4102/hts.v59i2.664

De Vos, A.S., 2002, Research at grass roots for the social science and human service professions, 2nd edn., Van Schaik, Pretoria.

Dreyer, T.F.J., 1998, 'Spiritualiteit, identiteit en die etos van die Nederduitsch Hervormde Kerk', HTS Teologiese Studies/Theological Studies 54(1/2), 289-314. http://dx.doi.org/10.4102/hts.v54i1/2.1409

Dreyer, T.F.J., 2003, 'Statistieke vertel 'n storie: 'n Visie vir die Hervormde Kerk op pad na 2010', HTS Teologiese Studies/Theological Studies 59(4), 1045-1062. http:// dx.doi.org/10.4102/hts.v59i4.685

Gadamer, H.G., 1989, Truth and method, 2nd edn., eds. J. Weinsheimer \& D.G. Marshall, Crossroad, New York, NY.

Heelas, P., 1993, 'The new age in cultural context: The premodern, the modern and the post-modern', Religion 23, 103-116. http://dx.doi.org/10.1006/reli.1993.1010

Janse van Rensburg, J., 2000, The paradigm shift: An introduction to postmodern thought and its implications for theology, Van Schaik, Pretoria.

Koekemoer, J.H., 1994, 'Die idioom van die Nederduitsch Hervormde Kerk: 'n Teologiese vraag', HTS Teologiese Studies/Theological Studies 50(1/2), 14-26. http://dx.doi.org/10.4102/hts.v50i1/2.2540

Koekemoer, J.H., 1995, 'Die etos van die Nederduitsch Hervormde Kerk', HTS Teologiese Studies/Theological Studies 51(3), 876-880. http://dx.doi.org/10.4102/hts. Studies 1447
v51i3.1447

Kuhn, T.S., 1987, The structure of scientific revolutions, University of Chicago Press, Chicago, IL.

Louw, D.J., 1999, Pastoraat as vertolking en ontmoeting: Teologiese ontwerp vir 'n basisteorie, antropologie, metode en terapie, hersiene uitgawe, Lux Verbi, Wellington.

McGrath, A.E., 1992, Bridge building: Effective Christian apolegetics, InterVarsity Press, Leicester.

Mead, L.B., 1994, Transforming congregations of the future, Alban Institute, Washington, DC.

Meylahn, J-A., 2012, Church emerging from the cracks: A church IN, but not OF the world, Sun Press, Stellenbosch.

Müller, J.C., 1996, Om tot verhaal te kom: Pastorale gesinsterapie, RGN, Pretoria.

Osmer, R., 2008, Practical theology: An introduction, William B. Eerdmans, Grand Rapids, MI.

Smit, C.J. \& Vorster, J.M., 2000, 'Die GKSA en sy Gereformeerde identiteit. Kan dit behou word in 'n postmoderne gemeenskap?', In die Skriflig 34(4), 515-573. $\mathrm{http}: / / \mathrm{dx}$.doi.org/10.4102/ids.v34i4.613

Van Eck, E., 2011, 'Redaksioneel tot die T.F.J. Dreyer Huldigingsbundel', HTS Teologiese Studies/Theological Studies 67(3), 6. http://dx.doi.org/10.4102/hts.v67i3.1124

Vorster, J.M., 1999, "n Waarskynlike bedieningsmilieu vir die GKSA in die dekades na 2000', In die Skriflig 33(1), 99-119. http://dx.doi.org/10.4102/ids.v33i1.1669 